\title{
The Evaluation of the Role of the Office for Protection of Competition of the Czech Republic in Regulating Public Procurement
}

\author{
Michal Plaček, František Ochrana, Martin Schmidt, Milan Půček ${ }^{1}$
}

\begin{abstract}
Our study offers additional insight into the Office for Protection of Competition. It examines the Office for Protection of Competition in terms of an input-processoutput model, defines the inputs needed for its activities and examines the outputs of its control activities. It also identifies external factors (in the environment) that affect the performance and behavior of the Office for Protection of Competition and have an impact on inspection activities. The theoretical background as well as assumptions are then subjected to empirical scrutiny. Theoretical conclusions and recommendations for more effective control of public contracts are drawn from the conclusions which are established.
\end{abstract}

\section{Keywords:}

Office for Protection of Competition, input-process-output model, public procurement, Czech Republic

\section{Introduction}

EU countries spend, on average, about $14 \%$ of GDP (European Commission 2014) on public procurement. In the Czech Republic, the volume of procurement was $13.7 \%$ of GDP in 2015 (see the Annual Report of Public Procurement 2014, MMR, May 2015). This is a large sum of public resources. It therefore makes sense to look for ways to streamline public procurement and to improve the monitoring systems of public procurement.

1 All: Faculty of Social Sciences, Charles University, Smetanovo nábřeží 995/6, Prague, Czech Republic. 
The economic literature on the monitoring of public procurement focuses mainly on the problems of efficiency in public procurement, creating a competitive and non-corrupt environment (see, e.g., Domberger and Rimmer 1994; Kuhlman and Johnson 1983; Lundsgaard 2002; Nemec and Grega 2015; Nemec et al. 2015; Mikušová and Nemec 2013; Nemec et al. 2015; Strand et al. 2011; Ochrana and Pavel 2013; Soukopová and Maly 2013). By comparison, the analysis of the control of public contracts by the Office for Protection of Competition (the OPC) has been relatively neglected. Examining the activity of the supervisory authority over public procurement is dealt with almost exclusively by legal works (see Bovis 2016; Graells 2015; in Jurč́k 2014). Institutional and economic study, however, remains neglected. In the scientific literature, we found only two economic studies (Pavel 2009; Schmidt 2014) which dealt specifically with examining the Office for Protection of Competition (Office for Protection of Competition) and the monograph Control in Public Administration (Nemec et al. 2010).

In his book The Effectiveness of the Functioning of the Control Systems of Public Procurement in the Czech Republic Pavel (2009) aimed to identify what the response from contractors was when the OPC found infringements of the rules of competition. The author of the second study is Schmidt (2014). It is inspired by the models of Andreoni (1991), Bose (1995), Lott (1996) and Motchenkova (2008) and performs an econometric analysis of the amount of fines imposed by the OPC. In this study, it was found that fines for administrative offenses in public procurement are not imposed at levels close to the maximum limit allowed by law, but account for an average of $4.4 \%$ of this value. Other factors affecting the amount of the fine were the estimated value of the public contracts, the number of offenses committed, the number of extenuating or aggravating circumstances, or the types of award procedures.

For now, it is worth exploring the OPC in terms of clarifying the operation of the Office from the perspective of an analysis of the resources used, an analysis of incentives to audit activities, as well as elucidating the external factors which influence the behavior of the Office. The monograph by Nemec et al (2010) examines the control system of public administration in the Czech Republic and the Slovak Republic. In the book, we find one paragraph which deals with the problem of control by the OPC and one paragraph which deals with the activities of "the Office for Public Procurement" in the Slovak Republic.

Our study offers additional insight into the Office for Protection of Competition. It examines the OFC in terms of an input-process-output model, defines the inputs needed for its activities and examines the outputs of its control activities. It also identifies external factors (in the environment) that affect the performance and behavior of the OFC and have an impact on inspection activities. The theoretical background as well as assumptions are then subjected to empirical scrutiny. 
Theoretical conclusions and recommendations for more effective control of public contracts are drawn from the conclusions which are established.

\section{Conceptual and theoretical framework}

We utilize the input-output-process-output model (see Leontief 1986, Lahr and Dietzenbacher 2001; Miller and Blair 1985) as the default tool for explaining the problem. We do not use quantitative analysis, however, but simplify and adjust it so that we can:

a) see how OFC works,

b) determine what the inputs, processes and outputs are,

c) simultaneously identify key external factors influencing the behavior of the OFC. A simplified diagram of the problem is shown in Figure 1.

\section{Figure 1}

The OPC as an input-process-output-outcome system

External factors determining the behavior of the OFC


Output: Number of

decisions issued, the volume

of fines and deposits appeal

against the OFC's decisions

Source: Authors

The model allows for the exploration of the OPC as a production system which transforms the given resources, during the process of its activities, into outputs and results of its inspection activities.

Regarding inputs, we will be observing the role of finance (budget changes) and staff (changes in the number of staff). The Office as a production system transforms given resources into its activities (review procedures) and generates outputs in the form of the effects of the review procedures. The inputs for decision-making at the Office also include a petition from actors (bidders) and the contracting authorities which prepare the tender documentation and announce the tender procedure. Regarding these actors, we assume that they make decisions in conditions of limited rationality (Simon 1959; Tversky and Kahneman 1981). Individual contracting authorities have different volumes and qualities of information and also different professional capacities to prepare tender documentation.

A number of external factors have a significant influence on the functioning of the OPC. These are such factors which actually (or potentially) affect the functioning and the existence of the Office. In particular, these include politicians, the 
government, the public and also the regulations and specifications regarding the functioning of the Office (Act No. 273/1996 Coll., regarding the competence of the Office for the Protection of Competition and from the review of public contracts and, understandably, the Public Procurement Act and the administrative procedure). We will monitor how the OPC will react to the impact of these factors in its activities. For signs ("indicators") of these reactions, we will consider the outputs (effects) from the review of the activities of the OPC.

\subsection{Institutional role and activities of the OPC}

The OPC is an independent central state administrative body. Its activities are established by law regarding the scope of the Office for the Protection of Competition. The OPC imposes (in addition to creating conditions for the promotion and protection of competition) its power in the exercise of oversight of the awarding of public contracts. Oversight over the awarding of public contracts means checking, by means of review procedures, public procurements.

The theory and practice differentiates between two models of review procedures - single-stage and two-stage review procedures (see Biandi and Guidi 2010). In the single-stage procedure, which can be described as the "mono-institutional", the procedures for the awarding of public contracts are subject only to judicial review. The single-stage review procedure is used in, i.e., The United Kingdom, Italy, Belgium and Sweden. In a single-stage review procedure, all operations which are related to the awarding of public contracts and to contracts, are handled by a single authority (a specific court). The Court has jurisdiction over the review of operations related to the awarding of public contracts while imposing remedial measures, ordering interim measures and making the ruling to rectify damage. In this case, however, it is typically possible to file an appeal with a higher court.

The Czech Republic (like Slovakia and Hungary) uses a two-stage model (biinstitutional) review procedure. As the name suggests, the processes of public procurement are reviewed in two stages or, respectively, two types of institutions, and in the course of each stage, there can be further appeal mechanisms. In the Czech Republic, the authority to review procedures in public procurements has been entrusted to the Office for Protection of Competition, therefore an authority outside the court system. The authority may, based on the results of the review procedure, decide to impose remedial measures or proceed to the imposition of fines. A party may also seek to appeal to a higher authority (lodged with the director of the office), which would be resolved by the Section of two-stage decision-making at the OPC. After exhausting all possibilities for redress within the OPC, a judicial review is also possible, which would take place before the Regional Court in Brno and possibly the Supreme Administrative Court. 


\subsection{Behavior of the OPC towards external actors and the associated impacts on its operation}

Since the OPC is a government authority that performs the rational choice in an uncertain world (Simon 1959; Hastie and Dawes 2010), we expect that in examining its behavior, we will identify "opportunity" as it is characterized by institutional economics (Williamsson 1981, 1991). In terms of its existence and ability to function, the OPC is, in fact, dependent on the decisions of external actors - especially legislators (creating the rules of its operation) and the government as an executive body that establishes the number of personnel and influences the level of its budget. We believe, therefore, that the Office will behave in an opportunistic manner towards these authorities. This may, for example, manifest itself in a way that will emphasize the social importance and necessity of their activities, as well as increase the amount of the assigned tasks, a side-effect of which may be the subsequent growth of its budget and staff (Niskanen 1971, 1994).

We expect that the behavior of the OFC will be characterized by such decisions and actions which will affirm the importance of its position. The role of assuming administrative proceedings ex officio is likely to be important in the OFC's activities, such as investigations, although they may have been initiated by a third party, but it is a procedure initiated on its own activity, whose launch depends on the sole discretion of the OFC. Such action corresponds to the logic of administrative behavior (Simon 1947) and the ideas of law and economics (Cooter and Ulen 2011; Friedman 2000).

We term the activities that the OFC carries out on its own initiative "activities with an expected effect of the decision." We understand that the result of the review activity, ex officio, it highly likely to result in a judgment imposing a fine or corrective action. The initiation of proceedings ex officio in fact occur mainly in cases where the OFC has doubt about the awards procedure in a given public contract upon preliminary investigation. The quantity of these proceedings is at the discretion of the OFC, which through an increase in their number may seek to increase the resources for their own activities. Such behavior, which consists of increasing the number of investigations in which violations of the law were found, meets the expectations of those actors (legislators) who set the regulations of the OFC and the actors who make decisions about allocating resources to the OFC, itself. Therefore, we believe that most of the outcomes of the examination procedure initiated ex officio, when completed, test positive for the imposition of a fine. A fine (as an output and an effect of the decision) is an instrument, which the OFC may use to outwardly express their "social importance" ("affirmation"). At the same time, we expect a definite increase in said proceedings. This is due to the prosecution of socially less serious infractions.

But we believe that if the OFC conducts a review investigation on external initiative, e.g. where administrative proceedings are initiated against a petition, it 
will opt for a more "opportunistic strategy". On the one hand, it will seek to reaffirm its social importance, but also, because it takes place in the conditions of a "bound rationality", it will proceed cautiously regarding its "administrative behavior" in order not to get bogged down in complicated problems. It will also likely avoid solving complicated and controversial cases that carry high transaction costs or loss of professional reputation, and in these cases it will look for different procedural grounds for termination of the investigation.

\section{Research questions}

With a view to the aims of this article, we have defined the following research questions which have been derived from our concept of the OFC's activities and is based on the model of input-process-output.

1. What are the inputs of the Office for the Protection of Competition and the factors that affect their dynamics?

2. How do the processes work and what are the probabilities of initializing individual actions?

3. What are the outputs of the office and what is the success rate of the OFC in their defense?

The aim of this study is to try to look for answers to the research questions, to discuss the achieved results of the examination and to make theoretical generalizations and recommendations for practice in the context of the theoretical framework and empirical analysis.

\section{Methods and data}

For the research, the following methods were used: desk research (especially in the analysis of administrative decisions and other documents of the OPC), interviews (consultations) with OFC.

Data were obtained from the website of the OFC (www.uohs.cz). For clarification and specification of information, we contacted the OFC in the form of an official inquiry. To analyze the impact of selected characteristics of public contracts, we used data on public contracts, whose announcement and awarding were published in the Journal of Public Procurement in 2007 and 2014 (including canceled contracts). The total is a set of 99,204 contracts. These data were combined with information about administrative decisions issued during the period of January 2011-March 2015. The given decisions are published in the Collection of decisions of the OFC. In total there were 1965 first-degree decisions. This data, however, contained more than one decision on the same contract or decision on contracts that are not published in the Bulletin (e.g. small-scale public contracts, cases where the 
contracting authority failed to publish or failed to track the corresponding entry). A total of 917 contracts searched for were included in the Bulletin of public procurement, which was led by the administrative management of the OPC. From these, 772 review procedures were initiated against the proposal, while in 295 cases it was noted that there had been violations of the law by the contracting authority.

We take into account the aspects of public contracts when defining selected characteristics which are available in the Bulletin of public procurement. Of these, we follow these characteristics of public contracts for our study: the type of the contracting authority (regional or local authority, national or federal authority, public institutions, regional or local authority, ministry or other body, other) and the type of tender (open, restricted, negotiated procedure without publication, negotiated procedure with publication, direct entry/award, other).

In this article, we do not use econometric models. We do focus, however, on the graphical representation of the probability of the impact of selected characteristics on the decisions of the Office for the Protection of Competition. To interpret the results, we have utilized the methods of analysis, synthesis and generalization.

\section{Results and discussion}

\section{Research question no. 1}

The first research question focuses on the analysis of financial and human resources needed to perform the review activities of the OFC. Clear data on the numbers of staff and budget amounts are shown in the following table.

Table 1

The numbers of staff and budget amounts

\begin{tabular}{|c|c|c|c|}
\hline Year & $\begin{array}{c}\text { Number of } \\
\text { Employees }\end{array}$ & $\begin{array}{c}\text { Employees in the Public } \\
\text { Contract Department }\end{array}$ & $\begin{array}{c}\text { Approved budget } \\
\text { (CZK) }\end{array}$ \\
\hline 2010 & 129 & 31 & $135,838,000$ \\
\hline 2011 & 161 & 50 & $138,868,000$ \\
\hline 2012 & 211 & 78 & $146,516,000$ \\
\hline 2013 & 214 & 79 & $230,187,000$ \\
\hline 2014 & 239 & 86 & $244,015,994$ \\
\hline
\end{tabular}

Source: Annual Reports of the OPC. Compiled by the authors.

From the data regarding the number of staff in individual years, it is clear that the changes in the numbers in the table (as well as in the structure of the Office) to a large extent depend on changes to the rules (Public Procurement Act) of public tenders. It is possible to point to a significant increase in staff in 2012, when a new amendment to the Public Procurement Act (No. 55/2012 Coll.) was adopted. It was 
adopted on the basis of a government bill. The aim was to enhance transparency in public procurement. At the same time there was a reduction in the thresholds for awarding public contracts in the Act. ${ }^{2}$ These are all factors that induced increased (additional) requirements for control (supervisory) activities within the OPC. The Office (quite rightly) called on the government to increase the number of staff as well as the budget. Towards this end, they used the advantage of information asymmetry and relatively easily achieved the increase in the number of staff as well as the budget. This issue in general is shown by Niskanen $(1971,1994)$.

The following chart further outlines the growth rate of complaints received, i.e. filed, which could serve as an impetus to initiate proceedings ex officio, while there is also an obvious increase in the number of filed complaints. Due to the significant proportion of complaints relating to contracts financed from EU subsidies as well as ones dealing with the subsidies given by relevant authorities, we assume that the increase in the number of complaints filed could, inter alia, be caused by a higher number of grant audits by the end of the project period.

\section{Graph 1}

Number of complaints filed with the OPC regarding public-procurement matters

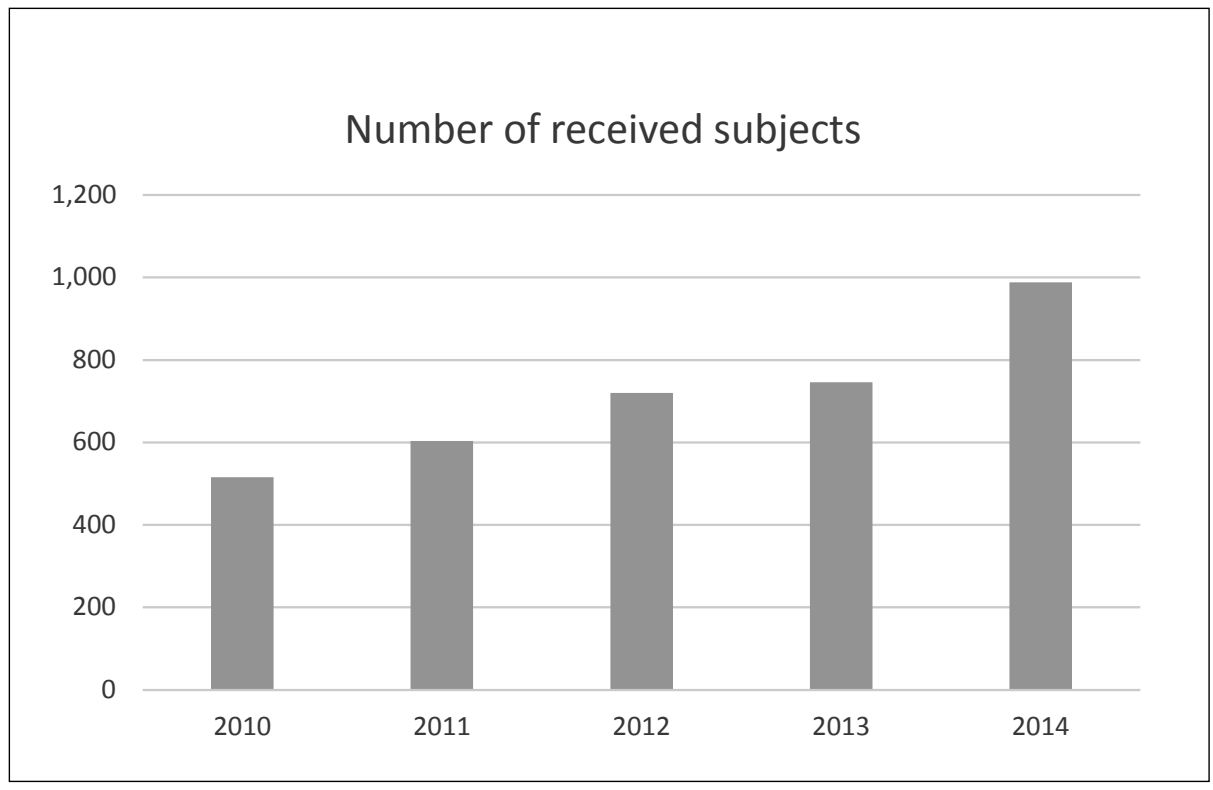

Source: Database of the OFC. Their own compilation.

2 These limits were again raised in 2014. 
We collectively state that if we look at the results through the lens of the bases defined in the theoretical part of our analysis, we can say that some of our results at first glance indicate a tendency towards increasing the budget as well as the number of personnel. The number of employees between 2010 and 2014 increased by $185.27 \%$ (of that, the department of public contracts by $277.42 \%$ ), and the total budget of the office increased by $179.64 \%$. The increase in the budget had the most dynamic shift between 2012 and 2013, which is partly related to personnel changes in 2011 and 2012. This increase was mainly caused by the increase in personnel due to the adoption of a transparency amendment to the Public Procurement Act (2012), which was due to an expected increase in the number of public contracts caused by a decrease in the limits on public contracts according to the Public Procurement Act.

\section{Research question no. 2}

The second research question is focused on the exploration of activities in the area of public contracts carried out by the OPC. According to our findings, the OPC mainly carried out these activities

- Making decisions on the submitted petitions and possibly imposing remedial measures,

- Saving public contracts on the basis of complaints, which can lead to the initiation of proceedings ex officio, which typically threatens the imposition of a fine,

- To a limited extent, the OPC is responsible for general inquiries and issuing guidelines.

As mentioned in the theoretical foundations, a mere investigation of public contracts carried out by the Office for Protection of Economic Competition can be held in two forms. First, there is a less formal investigation of a public contract based on a received complaint (as defined in $\$ 42$ of the Administrative Code), where if the Office finds suspicion that the alleged contracting authority's approach is not in accordance with the law, it will initiate administrative proceedings ex officio. The reality is that it depends solely on its own discretion whether the OPC launches proceedings or not.

Initiated administrative proceedings are already more formalized and governed by the relevant provisions of the Administrative Procedure Code. Administrative proceedings are concluded by a decision or the coming into force of the relevant decision (which subsequently leads to the publication of these decisions on the website of the OFC). Proceedings initiated ex officio typically lead to a fine. Less common are cases where a remedy is imposed or where there is a termination of the proceeding due to infractions of the law not being found.

The second group consists of administrative proceedings initiated at the request of the contractor (in accordance with $\$ 114$ of the Public Procurement Act), 
where formal proceedings commence automatically upon the delivery of a petition. The proposed proceedings have more participants, which is between the petitioner and the contracting authority (and possibly the selected tenderer), and OFC makes a decision regarding which side is in the right. It is often carried out in the investigation that a preliminary injunction will be issued prohibiting the contracting authorities from concluding a contract before the investigation has been completed. The supplier (petitioner), on the other hand, is required to pay a deposit (for the proceedings), which will be reimbursed if the petition is accepted. At proceedings based on a petition, the contractor seeks to impose a corrective measure consisting of cancelling a single act of the contracting authority or the entire procurement procedure. In these proceedings, the petitioner can therefore be ruled to have just cause and ordered corrective action (in this case, the contracting authority pays the costs in the amount of CZK 30,000). When the OPC agrees with the contracting authorities and rejects the petition, the deposit is forfeited ( $1 \%$ of the bid price, at least CZK $50,000)$ to the state budget. Administrative proceedings can also be terminated on procedural grounds, for example if the petition does not meet the appropriate requirements or if the party of the alleged misconduct corrects itself.

\section{Graph 2}

Number of administrative proceedings commenced in the area of public contracts, upon petition or ex officio

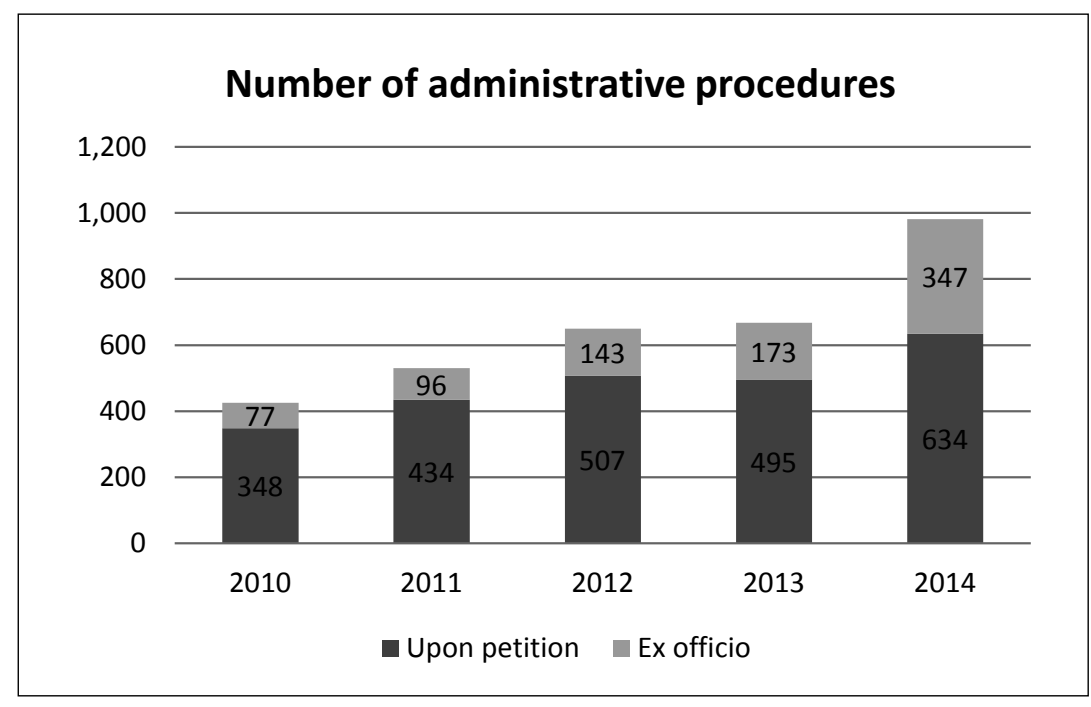

Source: Annual Reporting of the OFC. Their own compilation.

The chart clearly shows that the number of administrative procedures over the years has grown, the greatest growth is seen in ex-officio proceedings. The increase may be caused by two kinds of sources. First, there is the previously mentioned 
changes in the amendment to the Public Procurement Act and also the mentioned "opportunistic" (or "affirmative") behavior of the OPC toward outside authorities (legislators, government). It can be assumed that the Office is seeking increased confirmation (affirmation) in its monitoring activities to reaffirm its social importance and necessity. The increase in the number of petition-based proceedings, additionally, may relate either to changes in the law on public procurement, greater competition among bidders or information asymmetries of the appealing parties. They have comprehensive information about the problem and therefore rely on good faith in order to achieve success. Another cause may be speculative motives associated with the expected suspension and cancellation of the competition.

A part of the second research question also seeks answers regarding how selected factors influence the likelihood of actions being initiating by the OPC.

The following chart shows the average representation (probability) of the review procedures at the Office of Administrative Procedure (petition submissions, discovered irregularities) occurring for different types of contracting authorities.

\section{Graph 3}

The probability of the commencement of an investigation and the finding of legal infractions by the Office for the Protection of Competition according to the type of contracting authority

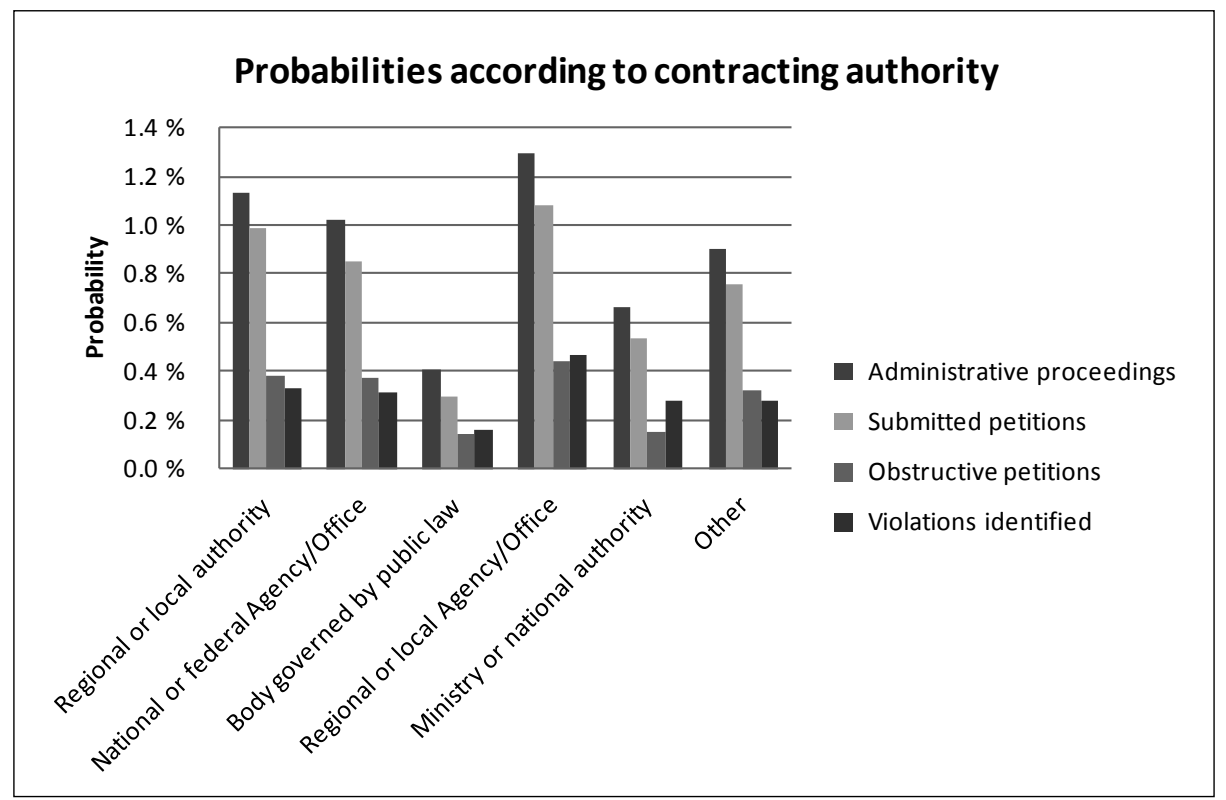

Source: Authors 
The chart shows clearly that, according to the classification of contracting authorities used by the Bulletin of Public Contracts, a greater likelihood of initiating proceedings lay with the regional and local authorities. ${ }^{3}$ This finding may be explained by the fact that the local authorities (unlike ministries) have a much less professional capacity regarding the quality required for the preparation of tender documentation. At the municipal level, the person who often handles the tender dossier has neither a legal nor an economic education. It is therefore more likely that there will be greater error at the local level.

The following chart shows the average representation (probability) of the review procedures at the Office of Administrative Procedure (petition submissions, discovered irregularities) occurring for different types of award procedures.

\section{Graph 4}

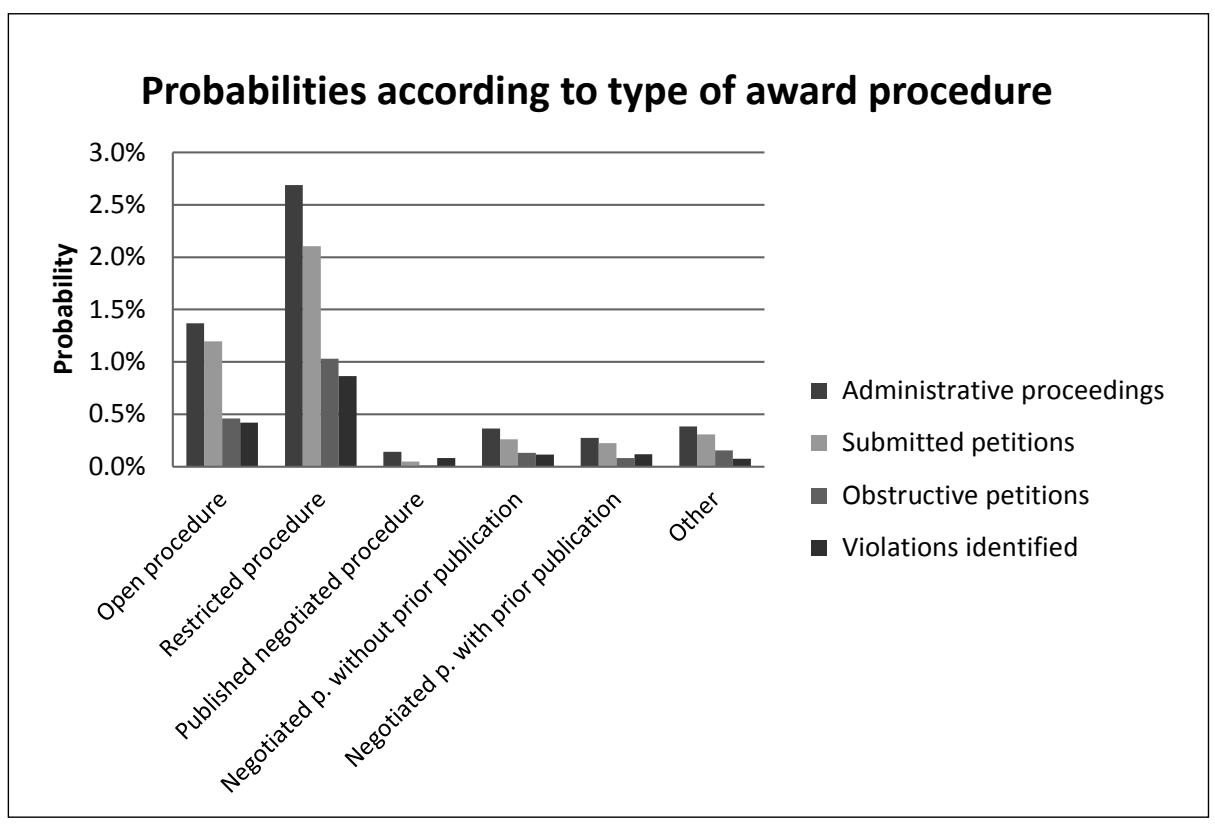

Source: Authors

The graph shows that the highest probability of initiating proceedings and violation of the law occurs in restricted award procedure. Probability values are significantly higher. In our opinion, this is due to the degree of competition when

3 It is very important to focus on the specific values of probability. The highest probability value of initiation of proceedings is the regional or local authority, and only $1.3 \%$. The contracting authority also achieved the highest probability of finding of misconduct by the Office for Protection of Competition, the specific value is $0.5 \%$. 
open and a restricted awarding process containing a higher level of competition than other types of award procedure and this leads to a higher motivation of unsuccessful suppliers giving petition to the regulator.

\section{Research question no. 3}

In research question number three, we will focus on analyzing the economic results of the OPC, the number of decisions handed down to the OPC and the success rate of the OPC during their defense.

The following table shows the "Economic balance" of the results of the OPC.

Table 2

The effects of decisions of the OPC on public contracts in a given year

\begin{tabular}{|l|c|c|c|c|c|}
\hline & $\mathbf{2 0 1 0}$ & $\mathbf{2 0 1 1}$ & $\mathbf{2 0 1 2}$ & $\mathbf{2 0 1 3}$ & $\mathbf{2 0 1 4}$ \\
\hline $\begin{array}{l}\text { total amount of } \\
\text { fines imposed }\end{array}$ & $\begin{array}{c}11,240,000 \\
\text { Kč }\end{array}$ & $\begin{array}{c}28,815,000 \\
\text { Kč }\end{array}$ & $\begin{array}{c}39,511,000 \\
\text { Kč }\end{array}$ & $\begin{array}{c}58,761,000 \\
\text { Kč }\end{array}$ & $\begin{array}{c}72,421,000 \\
\text { Kč }\end{array}$ \\
\hline $\begin{array}{l}\text { total amount } \\
\text { of imposed } \\
\text { costs of the } \\
\text { proceedings }\end{array}$ & $\begin{array}{c}1,898,000 \\
\text { Kč }\end{array}$ & $\begin{array}{c}1,746,000 \\
\text { Kč }\end{array}$ & $\begin{array}{c}3,420,000 \\
\text { Kč }\end{array}$ & $\begin{array}{c}3,519,672 \\
\text { Kč }\end{array}$ & $\begin{array}{c}3,067,000 \\
\text { Kč }\end{array}$ \\
\hline $\begin{array}{l}\text { amount of } \\
\text { combined } \\
\text { deposits }\end{array}$ & $\begin{array}{c}82,962,545 \\
\text { Kč }\end{array}$ & $\begin{array}{c}26,977,646 \\
\text { Kč }\end{array}$ & $\begin{array}{c}134,019,777 \\
\text { Kč }\end{array}$ & $\begin{array}{c}90,415,420 \\
\text { Kč }\end{array}$ & $\begin{array}{c}130,782,251 \\
\text { Kč }\end{array}$ \\
\hline $\begin{array}{l}\text { deposits } \\
\text { forfeited to the } \\
\text { state budget }\end{array}$ & $\begin{array}{c}9,254,300 \\
\text { Kč }\end{array}$ & $\begin{array}{c}5,464,009 \\
\text { Kč }\end{array}$ & $\begin{array}{c}5,688,881 \\
\text { Kč }\end{array}$ & $\begin{array}{c}16,349,779 \\
\text { Kč }\end{array}$ & $\begin{array}{c}6,546,700 \\
\text { Kč }\end{array}$ \\
\hline
\end{tabular}

Source: Annual Reports of the OPC.

As a partial evaluation of the research question, we can say that the dramatic increase of the collected fines by the OPC was very interesting. In the period from 2010 to 2014 the increase was $634.16 \%$; the greatest swing upwards occurred between 2012 and 2013. The proceedings initiated ex officio had a very similar increase compared to the above activities ( $450.65 \%)$. From the above information, it can be concluded that the increased activity of the OPC is fulfilling expectations. It has set the fight against corruption as one of its priorities. The number of administrative procedures is perceived by the government as an "indicator" of anticorruption activities in the field of public contracts. However, in our view, this is a simplified view of the problem.

Another possible explanation is related to the increase in personnel, budget growth and "opportunistic" behavior of the OPC towards external authorities. If the OPC has a larger number of staff, it may perform more review investigations, and therefore we can expect a greater number of fines imposed. The Office simultaneously demonstrates its own importance by the higher number of fines imposed and 
also wants to show outwardly that the growth of the budget and the higher number of staff leads "to larger effects" (a greater number of fines).

Based on our calculations (the average size of a public contract in 2014 was approximately 30.2 million CZK), we estimate that in 2014 (based on filed petitions or initiative) the OPC examined public contracts with a total value of 50 billion CZK, or approximately $9 \%$ of the value of public contracts awarded in that year.

The cases of review procedures ex officio confirm our assumption about the likely imposition of fines as a result of this proceeding. The imposition of fines occurred in $93 \%$ of these cases. This finding, together with an increase in the number of these procedures is consistent with the idea of "affirmation" (efforts of the OPC to demonstrate outwardly their "social necessity").

In the table below we analyze the decisions of the Office for Protection of Competition in cases of administrative proceedings commenced on the basis of a filed petition to investigate the actions of the contracting authority.

Table 3

OPC issued decisions from January-August 2015

in proceedings commenced by petition

\begin{tabular}{|l|c|c|}
\hline \multicolumn{1}{|c|}{ Decision } & Amount & Share (\%) \\
\hline Rejection of the petition & 62 & 22.3 \\
\hline Granting the petition & 55 & 19.8 \\
\hline Cessation due to petition withdraw & 43 & 15.4 \\
\hline Cessation due to failure to pay deposit or other formal errors & 48 & 17.3 \\
\hline $\begin{array}{l}\text { The contracting authority itself set aside the action or the } \\
\text { entire tender procedure altogether }\end{array}$ & 37 & 13.3 \\
\hline $\begin{array}{l}\text { Cessation due to the contracting authority concluding the } \\
\text { contract }\end{array}$ & 18 & 6.5 \\
\hline Other reason to stop the proceedings devoid of reason & 15 & 5.4 \\
\hline
\end{tabular}

Source: Reports of OPC, own calculations

As already mentioned, within the OPC, it is possible to use ordinary means of remedy. Proceedings for things specific to public contract before the OPC do not always have to finish once a decision has been handed down at the first level as any of the parties may take advantage of the appeal, by therefore filing an appeal to the Office of the Chairman (a parallel appeal). Since there is no fee for filing this appeal in any way, and since there is the possibility to achieve an extension of the length of administrative proceedings using this method, it is a widely used option.

The results of the submitted appeals against the decision of first instance is shown in the following graph and table: 


\section{Graph 5}

The number of appeals filed against the decision of first instance

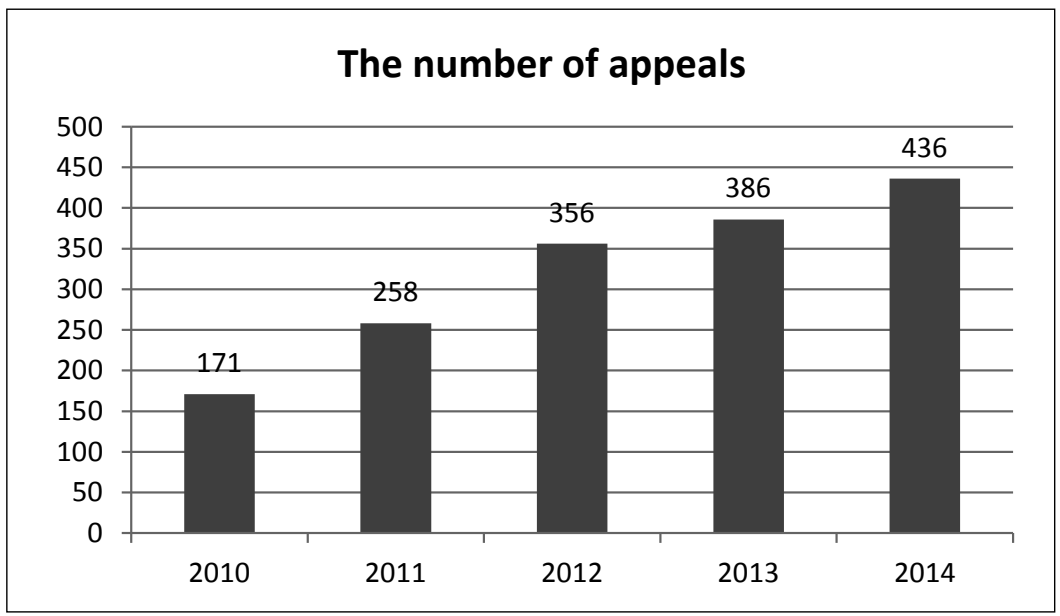

Source: OPC

Table 4

Issued decisions on appeals in individual years

\begin{tabular}{|l|c|c|c|}
\hline & $\mathbf{2 0 1 2}$ & $\mathbf{2 0 1 3}$ & $\mathbf{2 0 1 4}$ \\
\hline confirmed the decision of first instance & 169 & 189 & 224 \\
\hline annulled the decision of first instance and returned it & 46 & 44 & 37 \\
\hline process stopped & 14 & 49 & 107 \\
\hline Total & 229 & 282 & 368 \\
\hline
\end{tabular}

Source: Annual Reports of the OPC

Based on an analysis of the data and our calculations, it has been shown that the success rate of the submitted petitions (from the perspective of the petitioner) is quite small. This means that the OPC in most cases won based on its position. This may be due to various causes. Firstly, one cause may be the factor of informational asymmetry (a lack of information) on the part of the appellant, and, additionally, their appeal can be weighed down by subjectivism due to low professional (legal) capacity (some participants do not have their own legal services to aid in the appeals, nor do they have the finances to outsource legal assistance). The OPC is, however, a specialized department with the appropriate professional (legal) capacity to perform the review activities. It can be assumed that their findings will likely be correct. Another explanation offered is the "demonstrative behavior" of the OPC. Since the OPC is, in terms of its existence and operation, dependent on the decisions of 
external stakeholders (legislators, government,) it is not interested in "demonstrating" that the decisions it has arrived at will ultimately prove to be incorrect.

More insight into the issues of the demonstrative effect of the operations of the $\mathrm{OPC}$ is brought to light from the data regarding the success rate of proceedings before independent courts, meaning when there is an official judicial review of the situation.

Table 5

Success of the OPC before the courts

\begin{tabular}{|c|c|c|}
\hline \multicolumn{2}{|c|}{ Number of complaints submitted to the Regional Court in Brno } & 42 \\
\hline \multicolumn{2}{|c|}{ Number of cassation complaints filed to the Supreme Administrative Court } & 26 \\
\hline \multicolumn{2}{|c|}{ Number of lawfully terminated judicial proceedings in both instances } & 40 \\
\hline \multirow{2}{*}{ Of these } & Decision of the OPC confirmed & 25 \\
\hline & Decision of the OPC overruled & 15 \\
\hline \multicolumn{2}{|c|}{$\begin{array}{l}\text { Success rate of the decision of the Office with respect to the total number of } \\
\text { issued decisions (I and II instance) }\end{array}$} & $99 \%$ \\
\hline
\end{tabular}

Source: Annual Report of the OPC 2014

The $99 \%$ success rate of the OPC in relation to the total number of decisions (the number presented by the OPC) confirmed the information superiority of the office along with the effort to demonstrate an almost flawless course of decisionmaking authority. For comparison, the success rate of the OPC in the courts, measured against their decisions, against which administrative actions were actually filed, in the given year amounted to $62.5 \%$.

There is, in fact, not much relevant data available regarding the duration of the administrative proceedings before the OPC. The OPC, in 2015, followed the average period for issuing a decision of first instance by the Administrative Procedure Code. The resulting average was 32.95 days ( 41.8 days, excluding orders ${ }^{4}$ ). This indicator, however, is not relevant to the OPC in terms of the length of the investigation, since that period begins to run when the OPC has all materials available to it, and if the OPC detects any formal defects in the petition, this time limit is set to zero regardless of the actual length of proceedings. The mentioned period also ends with the release of the first-instance decision, and if an appeal is filed by any participant, the proceedings continue before the OPC at the second instance. According to our findings reached in 2015, the average time of issuance of a second-instance decision (upon receipt of appeal after the decision) is 154 days.

Based on our findings, we further note that there are efforts to decrease the length of time being taken to issue first-instance administrative proceedings. That could suggest that there are efforts of the OFC to prove its "social utility". However,

4 Form of decisions that may be issued at the beginning of simpler proceedings initiated ex officio (§ 150 of the Administrative Code). 
it should be noted that apparently the lengths of proceedings before the Office as a whole remain problematic, while relevant data to confirm this allegation were not available. This is probably related to the problem of "over-legislation", which is highlighted by Nemec et al. (2014). As a result of the extensive increases in legal regulation, the considerable clutter of the system has also increased. It also can induce increases in the budget and increases in administrative procedures. This phenomenon also creates space for partial inefficiency and creates "slack" for running the office.

\section{Conclusion}

The analysis of empirical data in most cases confirmed the theoretical background and presumptions which we mentioned in our study. The expected growth of budget and staff, which is caused both by legislative changes in the Public Procurement Act and probably the authorities' efforts to maximize the budget (see Niskanen's model of bureaucracy and inefficiency) was also confirmed. It also confirmed the increase in the number of review proceedings initiated ex officio, where the results of the proceedings are mostly positive. When filing an appeal, there was a very low success rate for the appellants. This may indicate a relatively high professional capacity of the OPC to conduct review procedures, but it may also indicate great efforts to demonstrate their professional capacity and social importance to the outside world. The analysis also showed that the probability of a review procedure depends on the professional capacity (or type) of the contracting authority. The likelihood of review proceedings is higher in governments than in central public-administration bodies. This is likely for local authorities (municipalities) as they do not possess the necessary legal services for the preparation of tender documentation. It turns out also that the probability of a review procedure is influenced by the type of procurement procedure. This information is particularly important for contracting authorities when deciding on the type of award procedures.

However, there were also some new problems and some issues that require further investigation. It turns out that a two-tier model of the review procedure seems complicated, less flexible and likely puts even higher transaction costs on processes related to the supervision of public procurement. What is missing is the necessary data which would enable the execution of a proper analysis confirming or rebutting that presumption (hypothesis). Addiotionally, even lawyers have reservations regarding the two-stage model of review procedures in the Czech Republic (see Jurčík 2014).

The assumption that the the OPC will avoid tackling complicated and controversial cases that carry high transaction costs and the risk of damage to their professional reputation and conversely deal with those that are not too complex, has failed to be proved or disproved exactly. That would have required extensive data and the performance of quantitative and qualitative research. This presumption has 
not been rebutted by us or in consultation with OPC experts (workers). This question remains open for further research.

In addition, it is not unequivocally demonstrated what the real economic effects of an increase in the use of resources are. The OPC reviews only the formal aspects of procurement procedures. It does not pursue economic indicators (e.g. "the rescued value"). Within its activities (in accordance with the Public Procurement Act) it monitors only the procedural aspects of public procurement. It does not pursue the economic effects of public procurement (value for money). It is an institution that persistently and stubbornly prevents the integration of the principles of $3 \mathrm{E}$ into the Public Procurement Act. It is also one of the reasons why we are unable to clearly answer the question what the economic effects of the review activities of the OPC are.

We may also conclude that the behavior of the office significantly influences the strategies of participants in the public-procurement market in terms of avoiding risk, but on the other hand, the OPC's decisions often does not lead to accountability and corrective measures.

\section{References}

Andreoni, J. 1991. "Reasonable Doubt and the Optimal Magnitude of Fines: Should the Penalty Fit the Crime?" RAND Journal of Economics 22(3), 385-395.

Biandi, T. and V. Guidi. 2010. The Comparative Survey on the National Public Procurement Systems Across the PNN. Autority for supervising public contracts. S. p. A. Roma.

Bose, P. 1995. "Regulatory errors, optimal fines and the level of compliance. Journal of Public Economics." 56 (3), 475-484.

Bovis, Ch. (ed.). 2016. Research Handbook on European Public Procurement. Cheltenham: Edward Elgar.

Cooter, R. and Th. Ulen. 2011. Law and Economics. $6^{\text {th }}$ edn. Pearson Series in Economics. New York: Prentice Hall.

Domberger, S. and S. Rimmer. 1994. "Competitive Tendering and Contracting in the Public Sector: A Survey." International Journal of the Economics of Business 1, 439-453.

European Commision. 2014. Public Procurement Indicators 2012. Brussels: European Commission.

Friedman, D. D. 2000. Law's Order. New Jersey: Princeton University Press.

Graells, A. S. 2015. "New Rules for Health Care Procurement in the UK: A Critical Assessment from the Perspective of EU Economic Law." Public Procurement Law Review 24, 16-30. 
Hastie, R. and R. N. Dawes. 2010. Rational Choice in an Uncertain World: The Psychology of Judgment and Decision Making. London: SAGE.

Jurčík, R. 2014. Veřejné zakázky a koncese. $2^{\text {nd }}$ edn. Praha: C. H. Beck.

Kuhlman, J. R. and S. R. Johnson. 1983. "The Number of Competititors and Bid Prices." Southern Economic Journal 50(1), 213-220.

Lahr, M. L. and E. Dietzenbacher (eds). 2001. Input-Output Analysis: Frontiers and Extensions. London: Palgrave.

Leontief, W. W. 1986. Input-Output Economics. $2^{\text {nd }}$ edn. New York: Oxford University Press.

Lott, J. R. Jr. 1996. “The Level of Optimal Fines to Prevent Fraud When Reputations Exist and Penalty Clauses are Unenforceable." Managerial and Decision Economics 17(4), 363-380.

Lundsgaard, J. 2002. "Competition Efficiency in Publicy Funded Service." OECD Economic Studies 35, 79-128.

Mikušová Meričková, B. and J. Nemec. 2013. “Contract Management and its Impact on Contracting Public Services: Slovak Republic.” Ekonomický časopis 61(7), 690-699.

Miller, R. E. and P. D. Blair. 1985. Input-Output Analysis: Foundations and Extensions. Cambridge: Prentice Hall.

Ministry for Regional Development. (2015). Výroční zpráva o stavu veřejných zakázek v České republice za rok 2014. Prague: Ministry for Regional Development.

Motchenkova, E. 2008. "Determination of Optimal Penalties for Antitrust Violations in Dynamic Setting." European Journal of Operational Research 189(1), 269-291.

Nemec, J. and M. Grega. 2015. "Factors Influencing Final Price of Public Procurement: Evidence from Slovakia.” Procedia Economics and Finance. Praha: Elsevier B. V., 543-551.

Nemec, J, M. Grega, M. Orviská and M. Šumpíková. 2015. “Selected factors determining the performance of the Czech public procurement system”. In Hájek, P., Mumanachyt, P. and Jone, A. M (eds.). Conference Proceedings: CBU International Conference. Praha: Central Bohemia University Praha, 242-247.

Nemec, J., F. Ochrana, J. Pavel and V. Šagát. 2010. Kontrola ve veřejné správě. Praha: Wolters Kluver.

Nemec, J., M. Šumpíková, S. Klazar and M. Grega. 2014. "Efficiency versus Economy in Public Procurement." In T. Löster and T. Pavelka (eds). Conference Proceedings: The $8^{\text {th }}$ International Days of Statistics and Economics. Praha: Melandrium, 1054-1063. 
Niskanen, W. A. 1971. Bureaucracy and Representative Government. Chicago: Aldine Atherton.

Niskanen, W. A. 1994. Bureaucracy and Public Economics. Cheltenham, UK: Edward Elgar.

Ochrana, F. and J. Pavel. 2013. "Analysis of the Impact of Transparency, Corruption, Openness in Competion and Tender Procedures on Public Procurement in the Czech Republic." Central European Journal of Public Policy 7(2), 116-137.

Pavel, J. 2009. Efektivnost fungování kontrolních systémů veřejných zakázek $v$ České republice. Praha: Transparency International.

Schmidt, M. 2014. "Pokuty za správní delikty ve veřejných zakázkách: ekonometrický model.” Acta oeconomica pragensia: vědecký sborník Vysoké školy ekonomické v Praze 2014(6), 35-50.

Simon, H. A. 1959. “Theories of Decision-Making in Economics and Behavioral Science." American Economic Review 49(3), 253-283.

Simon, H. A. 1947. Administrative Behavior: A Study of Decision-making Processes in Administrative Organization. New York. The Macmillan Company.

Soukopová, J. and I. Malý. 2013. "Competitive Environment in Waste Management and its Impact on Municipal Expenditures." Acta universitatis agriculturae et silviculturae Mendelianae Brunensis 61(4), 1113-1119.

Strand, I., P. Ramada and E. Canton et al. 2011. Public procurement in Europe: Cost and Effectiveness. Brussels: European Commission.

Špalková, D., J. Špalek and J. Nemec. 2015. "Performance Management and Performance Appraisal: Czech Self-Governments." NISPAcee Journal of Public Administration and Policy. Special Issue: Towards Meaningful Measurement: Performance Management at the Cross roads of Internal Efficiency and Social Impacts 8(2), 69-88.

Tversky, A. and D. Kahneman. 1981. "The Framing of Decisions and the Psychology of Choice Science." New Series 211(448), 453-458.

Williamsson, O. 1981. “The Economics of Organization: The Transaction Costs Approach." American Journal of Sociology 87(3), 548-577.

Williamsson, O. 1991. "Comparative Economic Organization: The Analysis of Discrete Structural Alternatives." Administrative Science Quarterly 36(2), 269-296.

Zákon 273/1996 Sb. dne 11. ř́ína 1996 o působnosti Úřadu pro ochranu hospodářské soutěže.

Zákon č. 99/1963 Sb., občanský soudní řád, ve znění pozdějších předpisů. 